\title{
ANNALS
}

O F

\section{The Entomological Society of America}

Volume XI

DECEMBER, 1919

Number 4

\section{THE TERMINAL ABDOMINAL STRUCTURES OF ORTHOPTEROID INSECTS: A PHYLOGENETIC STUDY.}

\author{
By E. M. WALker, Toronto, Ont.
}

INTRODUCTION.

There is still much difference of opinion concerning the inter-relations of the various orders of insects, particularly of the so-called "lower" orders, and even the question as to what are the limits of these orders is by no means a matter of general agreement.

If these problems are ever to be solved in a logical manner, all the available data must be taken into account. The evidence afforded by comparative anatomy, ontogeny and palaeontology, or any facts bearing upon the subject, must all be fairly considered. Although much information has been accumulated from these various sources, there are still important fields which have received much less attention than they deserve. In the field of external morphology the greatest advances have been made in the study of wing-venation, which, thanks to the classical labors of Comstock and Needham, now rests upon a thoroughly sound basis; the mouth-parts have also long been a favorite subject for investigation, while in comparatively recent years, good progress has been made in the study of the thoracic and cervical sclerites, particularly by Snodgrass and Crampton.

Our knowledge of the terminal abdominal structures, especially the genitalia and associated parts, is still, however, in a very unsatisfactory state. A constantly increasing value is being attached to them by systematists in separating genera 
and species, but the specialist is seldom interested in these structures except in so far as they afford good taxonomic characters in the groups with which he is concerned, and does not trouble himself to inquire into their homologies with the corresponding parts in other orders. The natural result of this is a multiplicity of terms and a great lack of unanimity in their application.

The most fundamental upheaval of our generally accepted ideas of insect classification that has occurred in comparatively recent years is the system advocated by the eminent student of fossil insects, Anton Handlirsch. This system, which was first proposed in $1903,{ }^{1}$ and elaborated in 1908 in his monumental work, "Die fossilen Insekten," is well known, and its deviations from previously accepted views are due mainly to the study of the fossil record. His division of the old class Insecta (Hexapoda) into five classes-Collembola, Campodeoidea, Protura, Thysanura and Pterygogenea-is not based directly upon palaeontological evidence, but on general considerations of structure; but the splitting up of the old order Orthoptera is founded upon the actual fossil record, so that the question as to whether or not the findings of comparative morphology support his views becomes one of considerable importance.

The present study of the genitalia and associated parts of the groups commonly called Orthoptera is offered as a contribution to this subject and, at the same time, an effort has been made to clear up certain general questions on the homologies of the parts concerned.

Before proceeding with the discussion of the terminal abdominal structures, it may be useful to give a brief summary of Handlirsch's views in so far as they relate to the origin and relationships of the various groups still commonly known as Orthoptera, i. e., the Blattidæ, Mantidæ, Phasmidæ, Acrididæ and Acrydiidæ (Tettigidæ)*, together with such other groups as may appear to be more or less closely related to them.

The earliest undoubted insect remains belong to the Carboniferous era. They are all winged insects of comparatively large size, some of them very large. Eleven orders are recog-

${ }^{1}$ Handlirsch, 1903. Zur Phylogenie der Hexapoden. Vorläufige Mitteilung. Sitzb. K. Akad. Wiss., Bd. 112, Heft 8, Abt. 1, pp. 716-738, Taf. 1.

* The Acrydiidæ of Most Authors. 
nized by Handlirsch as belonging to this period, only one of which, the Blattoidea, is represented among the orders of the present age, although four others, viz., the Protorthoptera, Protoblattoidea, Protodonata and Protephemeroidea, appear to be the direct forbears of the Orthoptera, Mantoidea, Odonata and Plectoptera (Ephemerida) respectively.

A large proportion of the insects of this period are characterized by their extremely generalized structure and are regarded by Handlirsch as the groups from which all other winged insects, or Pterygogenea, have descended. These are the Palaeodictyoptera. Their two pairs of ample wings were similar in size, form and venation, the latter being remarkably like the hypothetical type on which the Comstock-Needham system is founded.

The Protoblattoidea and Protorthoptera are independently connected with the Palaeodictyoptera by forms which differ very slightly from the latter, while, on the other hand, the most primitive Blattoidea, such as Polyctoblatta, grade almost insensibly into the Protoblattoidea. The latter group consisted of more elongate forms than the true Blattids, having a less regularly elliptical outline, and usually a longer prothorax and a more exposed and prognathous head. Some of them, at least, had a well-developed exserted ovipositor.

The Protoblattoidea died out in the Permian, where the first true Mantids appeared, these differing in venation very little from the former group.

The Blattoidea are considered to be the forbears, not only of their modern representatives, but also of the Isoptera, Corrodentia (Psocidæ), Mallophaga and Siphunculata (Anoplura). None of these groups are known before the Tertiary epoch, and the fossil record offers no clues as to their relationships. Handlirsch is probably correct with respect to the Isoptera, although they may well have arisen at a much earlier age than the Cretaceous.

The Protorthoptera, which also persisted into the Permian, embraced a considerable number of families and genera. They were elongate forms, some with ambulatory legs and prognathous phasmid-like heads, while others had saltatorial hind legs like those of modern Orthoptera. An elongated ovipositor was present in some, if not all, forms(e. g., Dieconeura arcuata Scudd.) None possessed stridulatory organs. 
No Orthopteroid insects are known from the Trias, the insect record of which is very scanty, but true Orthoptera appear in the Lias, belonging to several groups, some of which were silent while others possessed stridulating organs.

Among the former were the Locustopsidæ, which had antennæ and an ovipositor of the Tettigoniid type, but wing venation more like that of the Acridoidea, and, like the latter, lacked the stridulatory apparatus in the male tegmina. True Acridoidea are known from the lower Tertiary, so they were probably derived from the Locustopsidæ during Cretaceous times. The stridulating forms were in part, at least, true Gryllidæ, and Handlirsch concludes that from primitive nonstridulating saltatorial stock two branches arose, one leading to the common ancestors of the Gryllidæ and Locustidæ (Tettigoniidæ), the other giving rise to the Elcanidæ and Locustopsidæ, from which latter the Acridioidea were evolved. He regards the Tridactylidæ as probably derivatives of the Elcanidæ, some of which, like Tridactylus, possessed peculiar lobe-like swimming appendages on their hind tibiæ.

Other orders which Handlirsch assigns to the Orthopteran stem are the Dermaptera, "Diploglossata" and Thysanoptera. These groups are unknown below the Tertiary epoch, and this fact has evidently influenced Handlirsch's judgment in his attempt to find suitable ancestors for them in the Orthoptera of the Cretaceous.

The Ephemerida, Odonata and Plecoptera are considered to have no direct relationship with each other or with other orders except through their Palaeodictyopterous ancestors.

Since the publication of "Die fossilen Insekten," two new orders of insects have been discovered which must be considered in any discussion of the phylogeny of the orthopteroid groups. These are the Zoraptera, represented by a single genus, Zorotypus Silvestri ('13) 2 containing five species, and the Grylloblattoidea, likewise represented by one genus, Grylloblatta Walker $(' 14)^{3}$ with a single species (G. campodeiformis). The former group is compared by its author with the Isoptera and Blattidæ and also with the Dermaptera (teste Caudell) and

\footnotetext{
2 Silvestri, Fil., Ballet. Lab. Zool. Gen. Agric. Portici, Vol. VII, pp. 193-209, Figs. i-xiii (1913).

${ }^{3}$ Walker, E. M., Can. Ent., Vol. XLVI, pp. 93-99, P1. VI (1914).
} 
Crampton ('15) 4 considers them as probably members of the "Panisoptera," to which the first two named groups belong. Caudel15 likewise finds their nearest allies in the Isoptera. Unfortunately, I have been unable to obtain specimens of Zorotypus and can therefore add nothing to what has already been written concerning it.

The systematic position of Grylloblatta has been discussed in several papers by Crampton ${ }^{6}$, as well as in the original description by the present writer (1oc. cit.). Its extraordinary synthetic character is indicated by the variety of orders with which it has been found to have important features in common.

As regards Prof. Crampton's opinions on the relationships of the Orthopteroid orders in general, a few words may be said here. He has expressed views on this subject in several papers ('15, '16, '17, '18, '19) ${ }^{7}$ and these have been modified somewhat from time to time, especially with regard to the position of Grylloblatta, which will be discussed later. His latest views appeared in a paper entitled "Notes on the Phylogeny of the Orthoptera," and are summarized in his diagram on p. 43 ('19). ${ }^{7}$ They differ from those of Handlirsch mainly in the following points:

1. The Isoptera, owing to the possession of certain primitive characters not found in living Blattids and Mantids, are represented as arising, not directly from the Blattid branch, but from the base of the common stem of the Blattidæ and Mantidæ, or possibly somewhat farther along its path of development.

2. The Phasmidæ arose, not from Saltatorial Orthoptera (Locustopsidæ), but from near the base of the common Orthopteran stem, a view which is supported particularly by the presence of Plecopteroid characters in the primitive Phasmid, Timema californica.

3. The Dermaptera are likewise not regarded as of Orthopteran origin, but are separately derived from the common stock, from which all the pterygote orders arose.

\footnotetext{
${ }^{4}$ Crampton, G. C. Ent. News, Vol. XXVI, p. 343 (1915).

${ }^{5}$ Caude1l, A. N. Can. Ent., Vol. L, p. 381 (1918).

${ }^{6}$ Crampton, G. C., Ent. News, Vol. XXX, pp. 42-48, 64-65 (1919). (See also following footnote.)

${ }^{7}$ Crampton, G. C., Ent. News, Vol. XXVI, pp. 337-350, P1. XIII (1915); Ent. News, Vol. XXVII, pp. 244-258, 297-307 (1916); Can. Ent., Vol. XLIX, pp. 213-217, Fig. 9 (1917); Ent. News, Vol. XXVIII, pp. 398-413, PI. XXVII (1917); Journ. N. Y. Ent. Soc., Vol. XXV, pp. 225-237 (1917); Bull. Brooklyn Ent. Soc., Vol. XIII, pp. 49-68, Pls. II-VII (1918); Ent. News, Vol. XXX, pp. 42-48; 64-72 (1919).
} 
4. The Dermaptera, Embiidina and Plecoptera are grouped together more closely than is done by Handlirsch, who recognized no near affinities among them.

In other respects Crampton's diagram is not incompatible with Handlirsch's views, so far as it goes, but in regard to the relationship of other orders not included among the "Orthopteroid" groups, but believed by Handlirsch to be derived from Orthopteroid ancestors (including Blattoid and Protoblattoid derivatives) his views are very different. These, however, do not concern us here.

In general Crampton believes that the Plecoptera rather than the Blattoidea most nearly represent among living insects the ancestral stock from which the Orthoptera and Phasmoidea have developed, while Grylloblatta has its closest affinities among the Mantids, Embiids and Dermaptera, and its line of descent is therefore represented as coming from the ancestral stock common to the Panisoptera and Panplecoptera. This view differs somewhat from former views expressed by this same author, in which he placed Grylloblatta in his super-order "Panorthoptera," with the Orthoptera and Phasmoidea. The position of this important annectant form will be further discussed at a later stage.

\section{THE TERMINAL ABDOMINAL STRUCTURES.}

Two papers by Crampton ('17 and '18) ${ }^{8}$ have recently appeared, in which these structures in the more primitive orders are discussed from the comparative standpoint: In the earlier paper, which deals with the female, the author states that "the neck and cervical structures furnish far more definite characters for grouping these insects than the terminal abdominal structures of the female do," and in another paper already cited ('19, p. 64), he emphasizes the phylogenetic importance of the former structures on account of their being remarkably constant within an order or superorder and less subject to such variations as depend upon changes of function. While admitting the general truth of this statement, it should be kept in mind that such characters as were present in the common ancestors of all insects may be inherited by some of

${ }^{8}$ Crampton, G. C., Jour. N. Y. Ent. Soc., Vol. XXV, No. 4, P1s. XVI, XVII (1917); Bull. Brooklyn Ent. Soc., Vol. XIII, pp. 49-68, P1s. 2-7 (1918). 
the members of any of the orders, and that they may therefore be of little phylogenetic value except in determining the primitive form of the structure concerned or in deciding which forms in a particular group are its most primitive members. Specialized characters, when the factor of convergence can be eliminated, are often of more value than primitive ones, particularly in complex structures where an opportunity for detailed comparison is present. For instance, the arrangement of the mouth-parts of the Diptera or the Lepidoptera is so distinctive that these structures alone serve as recognition marks of these orders. It is largely this feature which renders wing-venation so useful in phylogenetic studies of insects, and although I should not attribute the same value to the genitalia, I do claim that they are of great phylogenetic importance when studied in detail; and in this connection I may point out that Prof. Crampton's studies of the thoracic and cervical sclerites are very much more thorough than those of the genitalia. The chitinous parts of the genitalia are in large measure internal structures and unless their internal relations are carefully investigated one is certain to be led to false deductions.

In another recent paper by Dr. A. G. Newell ('18) the view is held that the gonapophyses in both sexes represent three pairs of serial appendages or limbs, belonging to the 8th, 9th and 10 th abdominal segments; and an attempt is made to identify these appendages in both sexes of all the orders. Although a useful summary of the literature dealing with the subject of insect genitalia is given, the investigation itself betrays a lack of grasp of the fundamental principles involved, and the facts of comparative morphology and development as given in the bibliography cited appear to have been almost entirely ignored.

The material on which the present study is based was obtained from various sources. For the gift or loan of specimens, indispensable to the work, I am especially indebted to the following gentlemen, to whom I take pleasure in expressing my most sincere thanks: Prof. G. C. Crampton, Dr. C. Gordon Hewitt, Dr. N. Banks, Dr. L. O. Howard, Mr. Thos. E. Snyder, Mr. Morgan Hebard and Mr. W. Downes.

9 Newell, Anna Grace, Annals Ent. Soc. Am., Vol. XI, No. 2, pp. 109-142, P1s. IV-XVI. 


\section{Part I. The Terminal Abdominal Structures of the Female.}

The female external genitalia of a typical generalized Pterygote insect (e. g., Ceuthophilus, Figs. 1-4), consist of the vulva or genital aperture, situated at or near the posterior end of the eighth abdominal sternum and usually protected by a backward prolongation of the latter (in some cases the seventh sternum), the subgenital plate (st. 8); and three pairs of processes, the gonapophyses or valvula, which co-operate to form the ovipositor. These valvulæ are distinguished, from their usual positions, as the ventral, dorsal and inner valvule (valves) or the anterior, lateral and posterior gonapophyses, respectively. The ventral valvulæ arise primitively from the posterior margin of the eighth sternum, though often actually from the intersternal membrane between segments eight and nine; the dorsal and inner valvulæ from the ninth sternum, primitively also from the posterior margin.

The ventral, valvulæ (vv) consist of a shorter basal segment, the basivalvula (Crampton, '17) ${ }^{10}$ and a longer shaft. The basivalvula (bs) is usually chitinized only ventrally or ventrolaterally, if at all, the shaft externally, when a functional structure, but becoming partly or entirely membranous when the ovipositor is degenerate.

The dorsal valvulæ (vd) may be more or less distinctly separable into a broad proximal portion and a longer, more slender distal part, but there is no line of demarcation between these parts and nothing comparable to the basivalvulæ; the parts so designated by Crampton being in some cases the lateral part of the ninth sternum (or valvifer, vide inf.) ${ }^{11}$; in other cases merely the basal part of the valvula itself, ${ }^{12}$ the appearance of a suture being due to parts beneath showing through the valve.

The inner valvulæ (vi) are enclosed by the other two pairs and are usually the shortest pair. They commonly enclose or roof over, the passage through which the eggs are passed out

${ }^{10}$ Crampton, Journ. N. Y. Ent. Soc., Vol. XXV, p. 236 (1917). Also termed "Basalstück" (Van der Weele, Tijd. voor Ent., Deel XLIX, pp. 99-198, P1s. 1-3, 1906), and "basal plate"' (Walker, Univ. of Toronto Studies, Biol. Ser., No. 11, $1912)$.

${ }^{11}$ Crampton, op. cit., P1. XVI, Fig. 7; P1. XVII, Fig. 12.

${ }^{12}$ Crampton, op. cit., P1. XVI, Figs. 1, 6; P1. XVII, Fig. 10. 
in oviposition. Very frequently the inner valves are connected from the base distad to a varying extent by a fold of integument, which may be termed the intervalvular membrane (im). The inner valvulæ are generally chitinized laterally and these hardened parts or rami (rm) are connected by a strengthening bar or pons valvularum (p) across the membrane, or the entire fold may be chitinized dorsally. In the former case it is sometimes convenient to distinguish proximal and distal portions of the rami according to their position in relation to the pons. Like the ventral valvulæ, the dorsal and inner pair may be largely or wholly membranous when functionally degenerate.

Between the bases of the dorsal valvulæ and often closely connected or even fused with them, is a median sclerite, the superior intervalvula (sv). It bears a median vertical apodeme for the attachment of important muscles connected with the movements of the ovipositor, and its outer surface is continuous below with the upper surface of the intervalvular membrane. In some forms, such as Mantis and Stagmomantis, the rami of the inner valves may be fused with this plate. Another median sclerite, the inferior intervalvula (iv), is found on the ventral surface of the base of the intervalvular membrane. With the inferior intervalvula the rami of the inner valvulæ are frequently connected, as in the Tettigoniidæ and Acrididæ, and they are always connected more or less closely with a strong ventral process from the base of each dorsal valvula, which may be termed the inferior apophysis (iap). A similar but usually larger process, the superior apophysis (sap) projects forward into the hæmocœle from the upper part of the base of the valvula. Both pairs of apophyses serve for muscular attachment.

The dorsal and ventral valvulæ meet laterally at their bases, where they are both joined by a small plate, of more or less triangular form, the valvifer (Crampton) ${ }^{13}$ (vf). This sclerite represents the antero-lateral part of the ninth sternum and its outer (upper) anterior angle is connected with an apodeme in the form of a ridge following the constriction between segments 8 and 9 (ap. 9 , int. ap.). The ridge is generally continued along the front margin of the valvifer and also often along the lateral margin (using these terms in a morpho-

${ }^{13}$ The "épimerite" of Lacaze-Duthiers. Ann. Sc. Nat., 3 série, Zool., tome 17, pp. 207-251, Pls. 10, 11, 12 (1852). 
logical sense), and near its lower end it is sometimes raised into a prominent internal process (pap) for the attachment of muscles. In the Acridoidea this process reaches an enormous size, although the valvifer and ridge are greatly reduced or absent.

\section{Distal Valvular Connections.}

The manner in which the valvulæ are connected beyond the base varies greatly, depending upon differences in the methods of oviposition. As a rule the dorsal and ventral valvulæ form a sheath enclosing the inner valvulæ, the dorsal frequently overlapping or roofing over both ventral and inner valvulæ. Very frequently the inner and ventral valvulæ fit together more or less firmly by a tongue-and-groove joint extending along their adjacent outer edges for the greater part of their length, and in some cases (most Tettigoniidæ) such a joint also occurs between the dorsal and ventral valvulæ. In both cases the ventral valvulæ bear the groove or grooves, the other valvulæ the tongues. Where such connections exist the only possible movements of the valvulæ in relation to one another are sliding movements backwards and forwards. These are best seen in the Tettigoniidæ and doubtless also occur in Grylloblatta. In the Gryllidæ, in which the inner valvulæ are vestigial, the dorsal and ventral pair are immovably united with one another at the apices and no movement takes place between them. In the Acrididæ, Acrydiidæ and Tridactylidæ (Ripipteryx), on the other hand, the dorsal and ventral valvulæ are free beyond their bases, and can be moved in the sagittal plane like a pair of forceps, of which the dorsal pair form one of the jaws, the ventral pair the other. In the Phasmoidea, Mantoidea and Blattoidea, the valvulæ are more or less flexible and apparently not functional in the forms studied. There is no close connection between them beyond the base, although there is usually an ineffective tongue-andgroove engagement between the inner and ventral valvulæ.

\section{Development of the Ovipositor.}

The first indication of the ovipositor (Fig. 9) is generally a pair of tubercles on the ninth sternum, sometimes on the hind margin, but more frequently farther forward. These are soon followed by two other pairs, one from the hind margin of the eighth sternum, or just behind it, the other from the ninth 
sternum (Fig. 10), between the first pair and sometimes a little in front of them. The outer pair on segment 9 form the dorsal valvulæ, the inner pair the inner valvulæ, while the pair from segment 8 become the ventral valvulæ. Where styli occur, they may appear at an earlier stage than the papillæ, which are destined to form the valvulæ, and invariably occupy the same position as the outer papillæ of the ninth sternum, so that as these elongate into the valvulæ they carry the styli with them as small apical appendages. The styli, in all Orthopteroid insects, ultimately disappear or become indistinguishable from the apices of the dorsal valvulæ, but in many Odonata, including all the Zygoptera and some of the Anisoptera (Aeshninæ and Petalurinæ of the Aeshnidæ), well-developed styli persist in the adult females as functional organs.

In early larval life, when the first rudiments of the ovipositor appear, the abdominal segments are of relatively uniform size, decreasing in length but little towards the caudal extremity. In forms with a well-developed ovipositor (Orthoptera, Grylloblattoidea, Mantoidea), however, as development proceeds, the tenth segment becomes relatively smaller and the ninth deeper, so that, when maturity is reached, the sternal region of segment nine is shifted from a horizontal to a nearly vertical position, thus bringing the bases of the dorsal and inner valvulæ into the same transverse plane with those of the ventral valves. An enlargement of the bases of the valvulæ usually accompanies their increase in length and this brings about a crowding out, as it were, of such portions of the ninth sternum as are not occupied by the ovipositor itself. Thus, in the adult, the lateral areas are represented merely by the valvifers, while the median parts are the intervalvular membrane and the superior and inferior intervalvulæ.

In contrast to the reduction of the ninth sternum, the eighth sternum is usually prolonged caudad as the subgenital plate covering the vulva and bases of the ventral valvulæ. In some groups (Blattoidea, Mantoidea and Isoptera) it is, however, much reduced and hidden by the greatly developed seventh sternum, which replaces it as a subgenital plate. In such cases the eighth sternum becomes more or less completely dechitinized.

The important question as to the homologies of the valvulæ will be deferred until after the consideration of both the male and female structures in the various groups. 


\section{Orthoptera.}

\section{Tettigonoidea (Tettigoniidæ).}

As the ovipositor and associated parts in this group reach a high state of development and are at the same time of a remarkably generalized type, it seems best to consider it first.

The ovipositor varies enormously in length, form and armature, but with these features we need not be concerned. It will suffice for our purpose to examine one of the more primitive and one of the more specialized types.

Of the genera studied, we have found the most primitive types of ovipositor in the cricket-like forms belonging to the Stenopelmatinæ and Rhaphidophorinæ. The well-known "stonecrickets" belonging to the genus Ceuthophilus, of the latter subfamily, illustrate this type well.

In Ceuthophilus (e. g. C. lapidicola Burm.) (Figs. 1-4), the ovipositor shows comparatively little tendency towards the pronounced lateral compression or blade-like character of the more typical green grasshoppers and katydids. It is subcylindrical in the stouter basal part, becoming more compressed distally. The dorsal valvulæ overlap the other two pairs, completely concealing the inner valvulæ, and there is no tongue-and-groove connection between the dorsal and ventral valvulæ, such an engagement existing only between the ventral and inner valvulæ. The ventral valvulæ are closely applied together, meeting along the mid-ventral line. The basivalvulæ are distinct, though not heavily chitinized and are not wholly concealed by the rather small subgenital plate. Between the basivalvula, ninth tergite and base of the dorsal valvula, is the subtriangular valvifer, the upper angle of which is articulated with the ectal margin of the base of the dorsal valvula. Its antero-dorsal and antero-ventral margins are raised internally into strong ridges, (Fig. 4), the latter being continuous with the intertergal apodeme, which runs for a moderate distance along the front margin of the ninth tergite and terminates abruptly.

The inner edges of the dorsal valvulæ meet at a point near the base, proximad of which they diverge again slightly, but at the extreme base (excluding the superior apophyses) they are closely united by the small triangular superior intervalvula, which, as usual, projects beneath as a median vertical apodeme. 
The superior apophyses are triangular processes of average length. The inferior apophyses curve inwards to meet the inferior intervalvula, which is a large, thin, sagittiform plate.

The inner valvulæ are much shorter than the other two pairs and are somewhat widely overlapped by the dorsal valvulæ. The rami are connected across the well-developed intervalvular membrane, a little beyond its middle, by the broad pons valvularum, and are articulated at their bases with the inferior intervalvula behind the inferior apophyses. A portion of the proximal division of the rami is separated from the remainder by a distinct joint. The inner valvulæ are apparently supported by a strong chitinous process projecting inwards from the inner surface of the dorsal valvulæ at point about opposite the posterior limit of the intervalvular membrane.

The ninth and tenth segments are very short and the tenth tergite, as in all the groups of true Orthoptera, does not form a complete ring, there being a distinct though unchitinized sternal area. The eighth spiracle occupies the pleural membrane near the edge of the tergite.

The cerci are long and taper from a stout base to a slender apex. They are unsegmented, but it may be noted that in males of some species of the closely allied genus Pristoceuthophilus (e. g. P. cercalis Caudell) a few small segments are present at the apices of the cerci. Although this is very probably a caenogenetic character, it is of interest in connection with the other primitive characters met with in the subfamily Rhaphidophorinæ.

As an example of the more specialized type of ovipositor in the Tettigoniidæ, we may take Conocephalus fasciatus De Geer (Figs. 5-8). The ovipositor of this species is straight and sword-shaped, the valvulæ being more strongly compressed and closely coherent than in Ceuthophilus. Both dorsal and inner valvulæ engage the ventral valvulæ by tongue-and-groove joints, the groove in each case running along the edge of the ventral valvulæ. The basivalvula is not a distinct plate, but there is a flattened ventral area, which is evidently its equivalent. It is but little chitinized, except in its ventrolateral edge. The superior intervalvula is larger than in Ceuthophilus and shows a distinct external pocket or invagination and a well-developed median apodeme, extending down- 
wards and forwards. It articulates closely with the dorsal valvulæ. The pons valvularum occupies the entire distal half of the intervalvular membrane and is continued cephalad as a slender median process, which meets the under side of the superior intervalvula, but does not fuse with it. In some species, such as Tettigonia-verrucivora, according to Dewitz $(75)^{14}$, there is an actual fusion with this plate. The inferior intervalvula is a slender transverse bar, whose outer ends are closely articulated with the rami of the inner valvulæ, and less intimately with the inferior apophyses of the superior valvulæ, which terminate beyond the articulation in an upwardly bent spine. The dorsal apophyses are larger than in Ceuthophilus, but not essentially different. The valvifer and intertergal apodeme do not differ materially from those of Ceuthophilus.

The end segments are more elongate than in this genus, the tenth segment and anal valves more prominent. The cerci are shorter and there is a distinct cercal basipodite.

The female genitalia of Ceuthophilus may be regarded as somewhat more primitive than those of Conocephalus in the following characters: The distinct basivalvulæ, the less compressed ovipositor and the less complete cohesion of the valvulæ due to the absence of the tongue-and-groove joint between the dorsal and ventral valvulæ. The more elongate and flexible cerci might also be included, but it is in the males (vide postea) that they show a decidedly more primitive form than-in Conocephalus.

Finally, it may be added that in the Tettigonoidea in general the supra-anal plate is not divided transversely into two sclerites, as is commonly the case in the females of Acridioidea, i. e., there is no separate eleventh tergite; and it is not always sharply marked off from the tenth tergite. The paraprocts are generally but little chitinized.

\section{Grylloidea (Gryllidæ).}

In this group, as in the preceding, the ovipositor is typically long and slender, but, although sometimes compressed and ensiform or falcate, it is usually cylindrical and more or less enlarged apically, the enlarged part armed with teeth. In the Gryllotalpinæ or mole-crickets the ovipositor has wholly disappeared in adaptation to the subterranean habits.

${ }^{14}$ Dewitz, H., Zeits. wiss. Zool., Bd. XXV, pp. 174-200, Taf. 11, 12 (1875). (Tettigonia verrucivora referred to as Locusta viridlissima.) 
We may take as an example of the family the common field cricket (Gryllus assimilis Fabr.)

In this species (Figs. 11-15) the eighth and ninth tergites are very short in the mid-dorsal line, but the ninth expands considerably on the sides and extends farther ventrad than the others. The seventh sternum is very large, but is not produced caudad as a free flap, while the eighth sternum forms a small subgenital plate, similar to that of the Tettigoniidæ. The eighth spiracle occupies the pleural membrane close to the tergal margin. The tenth tergite is laterally very short, but is dorsally longer and fused with the supra-anal plate, though the line of fusion is visible. The paraprocts are larger and more heavily chitinized than is usual in the Tettigoniidæ. The cerci are long, flexible and tapering, with numerous hairs and sensillæ, being very similar to those of Ceuthophilus, though larger.

The valvifer is very large and is produced under cover of the subgenital plate into a strong process, which probably represents a part of the basivalvula. Its inner surface is without strong marginal ridges, but bears a stout process or apodeme, directed ento-caudo-dorsad. Its antero-dorsal angle is connected, as usual, with the ninth tergal apodeme, which is well developed. There is also a similar but weaker eighth tergal apodeme.

The ventral valvulæ are without distinct basivalvulæ, but these are represented by a well-defined unchitinized area, covered by the subgenital plate, and probably also by the ventral processes of the valvifers.

The dorsal valvulæ are peculiar in the sudden expansion of their bases, this part forming part of the sternal surface rather than the valves themselves. Between these bases and partly fused with them is the relatively large superior intervalvula. Like that of Conocephalus, its lower part is deeply depressed and it is also similarly produced cephalad into a thin median apodeme. The superior and inferior apophyses are well developed and the latter are connected by a transverse bar, which represents the inferior intervalvula.

The shafts of the dorsal and ventral valvulæ fit closely together by a tongue-and-groove joint and their enlarged apices are locked together by a peculiar structure, consisting of a projection from the dorsal valvula, which fits into a socket in the ventral valvula. 
The inner valvulæ are extremely vestigial and quite membranous. They project backward from the lower part of the superior intervalvula. They were overlooked by LacazeDuthiers (loc. cit.), who mistook the dorsal valvulæ for them, owing to their close connection with the inferior intervalvula, which is suggestive of the connection in many Tettigoniidæ between this plate and the rami of the inner valvulæ.

In Oecanthus (Figs. 16-18, Oe. quadripunctatus Beut.) the genitalia do not differ from those of Gryllus except in comparatively unimportant details. The most striking feature is the exceedingly powerful ninth tergal apodeme, which forms a complete arch around the base of the tergite; and the otherwise feebly chitinized dorsal surface of segments 9 and 10 . These features are doubtless related to the habit of the genus of ovipositing in woody stems, which would require a greater development of the muscles of the ovipositor than is necessary in such ground-dwelling species as Gryllus assimilis.

The dorsal and ventral apophyses and the ventral prolongation of the valvifer are also longer than in Gryllus.

The general proportions of the abdominal segments and terminal structures are somewhat suggestive of some Tettigoniida and of Grylloblatta, but there are no indications of relationship with the latter form, as has been more than once suggested by Crampton, who has been apparently influenced by superficial resemblances of form. As far as the terminal abdominal structures are concerned, Oecanthus is more specialized than Gryllus, and if anything even less like Grylloblatta than the latter genus is.

\section{Acridoidea (Acrididæ, Acrydiidæ).}

The appearance of the ovipositor in this superfamily is singularly different from that of the two preceding groups, but the fundamental similarity of its structure in all three was demonstrated long ago by Lacaze-Duthiers ('52, loc. cit.) and Graber ('70) ${ }^{15}$. Its peculiarities in the Acridoidea are chiefly modifications connected with the different method of oviposition. The dorsal and ventral valvulæ function as a pair of forceps for digging the hole, usually in the ground, in which the eggs are deposited. Each pair of valves acts as one of the

\footnotetext{
15 Graber, V., Sitzb. K. Akad. Wiss., Bd. LXI, Abt1. 1, pp. 597-616, 1 P1. (1870).
} 
blades of the forceps, the movements being in the sagittal plane. The inner valvulæ take no part in this process, but serve to roof over the path along which the eggs are passed out.

As a type of the group we may take the common twostriped locust (Melanoplus bivittatus Say.) (Figs. 22-25). In this species the eighth tergite is well developed, but the ninth and tenth are not only greatly shortened, but are fused laterally, the intersegmental furrow being imperfectly developed. The supra-anal plate is divided by a transverse suture, the basal part probably representing the eleventh tergite, while the apical part is the tergite of the anal segment or telson. There is also a distinct cercal basipodite, which may represent a separated lateral portion of the eleventh tergite. The cerci themselves are very short and unsegmented. The paraprocts are broad, flat and well chitinized, and are not completely separated from the tenth tergite at the lateral margin.

The abdominal tergites are in reality pleuro-tergites, since they bear the spiracles, a short distance from their lateral margins. This feature is more pronounced in the Acrididæ than in other families of Orthoptera. The eighth sternum forms a large subgenital plate and terminates in a papilliform process called the "egg-guide," another characteristic Acridian structure.

The ventral valvulæ are short and very stout at base, but taper to a slender decurved hook-like apex. They are peculiar in that the tegument is divided into five distinct sclerites, of which the lateral and the three ventral ones constitute the basivalvula, while the long dorsal one represents the shaft. This is evident by comparison with Acrydium in which there are but three sclerites. The dorsal valvulæ are of about the same length as the ventral, and the apices are likewise hooklike, but curved upwards. They are narrowly separated at base, the interval being occupied by the small superior intervalvula, which lacks the usual median apodeme, but has two slight prominences for muscular attachments.

The superior apophyses are represented only by thin flat tendons of the powerful elevator muscles of the dorsal valvulæ. The inferior apophyses (Fig. 24), on the other hand, are stout processes which bend inwards from the base of the valvulæ to articulate with the inferior intervalvula. This plate has the form of a curved bar, from the concave side of which a bifurcate 
process arises. The inferior apophyses join the ends of the bar, while the arms of the bifurcate process are connected with the rami of the inner valves. These connections are thus quite similar to those of the Tettigoniidæ (cf. Ceuthophilus).

The inner valvulæ are very short, but not vestigial as in the Gryllidæ. They are connected almost to their apices by the intervalvular membrane, the rami being united distally by a $\mathrm{V}$-shaped pons valvularum.

Extending cephalad from the basal articulation of the dorsal and ventral valvulæ into the body-cavity as far as the seventh segment is a somewhat flattened and heavily chitinized rod (pap), which is entirely concealed in an external view. This structure appears as though grooved externally, but the groove is covered over with thin chitin, so that it is really a tubular invagination. It serves for the origin of the most powerful muscles of the valvulæ, i. e., the elevators of the dorsal and depressors of the ventral valvulæ. Its morphological nature has been the subject of differences of opinion. Lacaze-Duthiers (loc. cit.) interpreted it as the "épimerite" (valvifer), while Graber (loc. cit.) thought it represented the superior apophysis of the dorsal valvulæ. The latter interpretation is obviously incorrect; the former is much nearer the truth. The muscles, which in other Orthoptera arise from the ninth tergal apodeme and its vicinity and are inserted into the superior apophyses, take their origin in the Acrididæ from this rod, the apodeme being undeveloped in its usual situation. It will be remembered that this apodeme is continuous with that of the lower edge of the valvifer in the Tettigoniidæ and other groups, and that it tends to be best developed towards its lower end, where it is sometimes raised into a distinct process (e. g. Diapheromera, Stagmomantis). As the muscles which usually connect the valvifer with the superior intervalvula arise in Melanoplus also from this process, it appears that the latter represents in part the lower end of the tergal apodeme and in part the valvifer. That it does not represent the main body of the latter is clearly shown by an examination of both nymph and adult of one of the small grouse-locusts (Acrydiidæ, more commonly known as Tettiginæ). Fig. 28 represents the end-segments of the female nymph of Acrydium ornatum Say. Here we find a perfectly typical valvifer of considerable size. In Fig. 26, which is taken from an adult Acrydium, the valvifer is also 
present, but is very small and sub-chitinized. The characteristic rod (pap) is fully developed and is separate from the valvifer, but its base of attachment is in very close relation to the latter; in fact, in an internal view of the nymph, they appear to be in contact with one another.

The first appearance of this rod in the nymph of Melanoplus is a slight invagination of the soft chitin at the angle between the valvular bases. This is later continued cephalad as a thin band-like tube, as seen in the last nymphal stage, assuming its final form only at the last moult. No external appearance of the valvifer is present in Melanoplus.

In respect of the presence of a distinct valvifer in the Acrydiidæ we may consider the latter to be a more primitive family than the Acrididæ and this view is borne out by other features of the terminal segments: In the nymph of Acrydium, e. g., the ventral valvulæ possess unmistakable basivalvulæ (bs), which, however, in the adult became divided into two sclerites, a lateral and a ventral, the latter representing the two principal ventral sclerites in Melanoplus. The ninth and tenth tergites are quite separate and less reduced than in Melanoplus, especially in the nymph. The tenth tergite (Fig. 29) is imperfectly divided into median and lateral regions, of which the former is less heavily chitinized and is produced caudad into a lobe which divides the eleventh tergite into two separate lateral plates. The supra-anal plate also shows two lateral chitinized areas. In the nymph (Fig. 29), the eighth and ninth tergites are unmodified, but in the adult they also present a narrow, less densely chitinized median region, which folds inwards, allowing the lateral parts to come together in a pointed or Gothic arch.

These peculiar features are very suggestive of the Tridactylidæ, which also resemble the Acrydiidæ in some other respects. The cerci are divided into a stouter basal part, which is hairy, and a slender smooth apical part. This gives them the appearance as though composed of two fused segments, a feature which is also suggestive of some Tridactylidæ (q. v.).

In other respects the female genitalia closely resemble those of the Acrididæ, the larger size of the superior intervalvula in Acrydium as compared with that of Melanoplus being perhaps the most striking difference noted. 
The eighth spiracle, as in other Acridioidea, is situated in the tergite (pleuro-tergite), but the others retain a more primitive position in the pleural membrane.

\section{Tridactyloidea (Tridactylidæ).}

This small family has been commonly associated with the Gryllidæ, owing to the superficial resemblance of the typical genus, Tridactylus, to the mole-crickets (Gryllotalpinæ), a resemblance due to the subterranean habits of both. Thus we find in both Tridactylus and Gryllotalpa a similar form of head and pronotum, short antennæ, front legs adapted for digging and reduction of the ovipositor, which in Tridactylus is vestigial, while in Gryllotalpa it is entirely wanting. In the Tridactylid genus, Ripipteryx, however, which is not a distinctly subterranean form, there is a well-developed ovipositor, and it is not at all like that of a Gryllid, but is remarkably similar to that of the Acridoidea, as suggested by de Saussure and Zehntner ('94).16 These authors, however, failed to appreciate fully this resemblance and made no comparisons between the two groups.

I have examined the terminal segments and ovipositor of Ripipteryx forcipata Sauss. (Figs. 19-21), and find the latter to be closely comparable with that of the Acridoidea, but with certain important features of its own.

The obliquity of tergites $9-11$, which is slightly indicated in Acrydium and associated with the weakening of the median region and a breaking up of the dorsum into a number of secondary sclerites, occurs in the Tridactylidæ in an exaggerated form. In $R$. forcipata the eighth tergite is normal in shape and form except that it is divided along the mid-dorsal line into two lateral plates, the thin tegument between the plates being folded inwards. This is also the case in a slighter degree in Acrydium. The ninth tergite is also completely divided into two lateral plates, but the obliquity has been carried so far that the original anterior, ventral and posterior margins are respectively ventral, posterior and dorsal in position. The antero-dorsal angles of these plates extend forward underneath the eighth tergite as two slender processes, which are apparently all there is to represent the dorsal region. The tenth tergite lies dorsal to

${ }^{16}$ Rev. Suisse de Zool., tome II, Fasc. 2, pp. 403-430, P1s. XVI, XVII (1894). 
the ninth, and consists of two narrow lateral plates prolonged forward into a pair of slender, curved bars, which pass between the similar processes of the ninth tergite, under cover of the eighth tergite, but meet in the middle line between the two main parts of the latter and three other small plates which apparently represent the median elongated portion of this tergite in Acrydium. The eleventh tergite is possibly represented by the two small oblique plates at the base of the supra-anal plate, and two others laterad of these at the bases of the cerci (cercal basipodites). These relations are also similar to those of the Acrydium. The cerci are short, cylindrical and unsegmented, although in Tridactylus they are distinctly two-segmented, and in certain other species of Ripipteryx ( $R$. mexicana Sauss.) they are imperfectly divided into a number of secondary segments (de Saussure \& Zehntner, loc. cit.).

The supra-anal plate is similar in form to that of Acrydium but is semi-membranous and undivided. It varies, however, considerably in form in different species of the family, as do also the subdivisions of the abdominal tergites, so that it is questionable to what extent these parts are really homologous to those of the Acrydiidæ.

The paraprocts are of very remarkable form, being greatly elongated, with a terminal segment like a pair of styli or a second pair of cerci. These, however, have nothing to do with true styli, for which they were mistaken by Crampton ('18) ${ }^{17}$; for the styli, when present in female insects, are always borne by the dorsal valvulæ or their homologues, and thus belong to the ninth segment. These peculiar structures, which are present in both sexes in Tridactylus as well as Ripipteryx, were correctly interpreted by de Saussure and Zehntner as outgrowths of the paraprocts.

Another feature possessed by Ripipteryx in common with Acrydium is the position of the eighth spiracle in the eighth tergite, and the other spiracles in the pleural membranes.

Turning to the sternal region, we find that, except in the case of the eighth, the sternites overlap the tergites instead of vice-versa. The eighth sternum forms the subgenital plate, but is not specially modified for the purpose and lacks an egg-

${ }^{17}$ Bull. Brooklyn Ent. Soc., Vol. XIII, No. 7, P1. V, Fig. 48, 1918. 
guide. The basivalvulæ are of enormous size and have the appearance of a divided subgenital plate, for which they were mistaken by de Saussure and Zehntner.

The ovipositor as already noted, is essentially Acridian in type. The dorsal and ventral valvulæ are sigmoid in form, the apices of the dorsal valvulæ curving upwards, the ventral pair terminating in sharp, decurved hooks, and having also a shorter external hook (cf. Melanoplus, Figs. 22, 23). In de Saussure and Zehntner's Figure (1. c., P1. XVII, Fig. 27) what is evidently the same hook is represented as belonging to the dorsal valvulæ, but this is certainly an error, due to the valvulæ having been tightly closed in the specimen drawn. As in most Acridoidea there is no trace of the valvifer, while the free chitinous rod (pap) is represented by a prominent, shelf-like apodeme (ap 9), extending from the angle between the valvulæ along the ventral edge of the ninth tergite and projecting a short distance under the eighth. This ridge is quite similar in relation to the valvulæ to the free rod of the Acridoidea, but is a true ninth tergal apodeme, like that of the Gryllidæ and Tettigoniidæ. It is in this feature that the genitalia of the Tridactylidæ differ most from those of the Acridoidea.

The dorsal valvulæ, as in the Acridoidea, lack distinct superior apophyses. The superior and inferior intervalvulæ have precisely the same positions as in. that group, but are even smaller and simpler in form. The inferior intervalvula is a slender transverse bar resembling that of Gryllus in form and is connected at its outer ends, separately, with both the small inferior apophysis and the rami of the inner valvulæ. The latter are, as in the Acridoidea, very small, but lack the intervalvular membrane and pons.

There are many other points of resemblance between the Tridactylidæ and Acridoidea, and taking all these into consideration, we can hardly doubt that the nearest relations of the former are the Acridoidea rather than the Gryllidæ. 


\section{Grylloblattoidea (Grylloblattidæ).}

The female genitalia of the Orthoptera are most nearly approached by those of Grylloblatta, so that we may consider this form next.

A glance at the end-segments and ovipositor of Grylloblatta (Figs. 31-35) at once recalls the Orthopterous families Gryllidæ and Tettigoniidæ, except in the segmented cerci, which are more like those of certain Plecoptera, or to a less extent, the Mantidæ. The form of the eighth, ninth and tenth segments is very like that of Conocephalus, though more depressed and the tenth segment more prominent. The eighth sternum is not flap-like, but quite generalized in form, although a median pale or thin area is present, which marks the small cavity into which the vagina opens.

The ninth tergite (Fig. 31) is somewhat prolonged ventrad as in Gryllus, the ventro-cephalic margin being oblique, as is usual in the Tettigoniidæ and Gryllidæ. The tenth tergite in the adult female is fused with the sternite forming a complete ring, as in many Plecoptera. Its dorsum is slightly prolonged behind the bases of the cerci, but does not overlap the supraanal plate, which is quite distinct, though small. Both supraanal plate and paraprocts, which are subchitinized, are quite like those of many Tettigoniidæ. The spiracles, which are very small, are all situated in the pleural membrane.

In the external form of the valvulæ and their connections with neighboring sclerites Grylloblatta is remarkably like a primitive Tettigoniid, such as Ceuthophilus. The most conspicuous, but not the most important difference is in the basivalvulæ, which are more clearly defined and more heavily chitinized, recalling those of the Mantids. The valvifer has exactly the same relations as in the Tettigoniidæ. Its lower angle articulates with the ecto-basal angle of the ventral valvula, not being prolonged under the subgenital plate as in Gryllus and Oecanthus. There are well-marked internal ridges along its upper and lower margins, the latter being continuous with the ninth tergal apodeme, all these features recalling Ceuthophilus or Conocephalus strongly.

The ovipositor is much like that of Ceuthophilus or related genera, though the valvulæ are less compressed and not so closely applied to one another, the ventral ones, particularly, 
being slightly separated from one another along the mid-ventral line and from the dorsal valvulæ along their entire length. The dorsal valvulæ do not overlap the ventral valvulæ on the sides, so that the inner valvulæ are not concealed as in the Tettigoniidæ. The inner valvulæ are a little shorter than the ventral, with which they are connected by a tongue-and-groove joint of the same character as in Ceuthophilus, i. e., there is a narrow groove with raised edges along the upper margin of the ventral valves, into which fits a ridge along the lower margin of the inner valves.

In order to study the inner connections of the valvulæ the abdomen of the original paratype specimen was cut across at the base of segment seven, and the posterior segments treated with potash.

Fig. 32 shows the ovipositor in dorsal view, with the left ventral valve forcibly turned outwards; the right valve is omitted. The dorsal valves are separate from one another except near the base, where they meet at little more than a point, the inner margins then diverging again. The superior apophyses are very like those of Ceuthophilus (Fig. 1) and the articulations with the valvifer quite similar. The inferior apophyses are prolonged inwards into a pair of slender curved bars, which meet one another in the middle line. These evidently represent the inferior intervalvula, but are in no way distinct from the apophyses.

The inner valvulæ fit closely into the concavities of the dorsal valvulæ, there being no space between the two pairs such as we usually find (cf. Ceuthophilus). The intervalvular membrane is well-developed as is also the pons which unites the rami just beneath the point where the dorsal valvulæ meet. The median part of the pons projects below from the upper surface, as a bilobed prominence (Fig. 35, pp), which recalls the transverse thickened portion of the superior intervalvula in the Mantids (Figs. 35, 49). No median apodeme could be found, however, and it is to this apodeme that the muscles arising from the valvifers are attached in the Mantidæ, Tettigoniidæ and Gryllidæ. This apodeme, when present, is situated between the valvifers, the muscles running transversely and if such an apodeme were present in this position in Grylloblatta it would lie considerably in front of the bilobed prominence. 
The fact that the valvifers are well chitinized and bear the usual ridges for muscular attachment seems to indicate, however, that the muscles in question are probably present and yet no sclerite for their inner attachment was found, unless it be the bilobed prominence. As compared with Ceuthophilus this prominence would appear to belong to the pons, but in any case it seems probable that the pons was primitively not distinct from the superior intervalvula, as is indeed the case in such forms as the Mantids where no distinct intervalvular membrane is developed. With the great development of this membrane in the Tettigoniidæ, however, the pons became differentiated, retaining its connection with the superior intervalvula in some forms (e. g., Tettigonia) while becoming entirely separated from it in others, such as Ceuthophilus. Although the matter requires further investigation, it may be considered probable that the superior intervalvula is at least partly represented by the bilobed prominence beneath the pons. If this is the case, Grylloblatta differs from all the other forms studied in which the superior intervalvula is present in that this sclerite does not connect the bases of the dorsal valvulæ, but lies beneath them.

The rami of the inner valvulæ are fused with the inferior apophyses which, as stated above, is not distinct from the inferior intervalvula. This firm union of the dorsal and inner valves, together with the manner in which the latter fit closely within the former, would seem to prohibit any independent movements of the inner valvulæ.

A short distance behind the united inferior apophyses is the opening of the receptaculum seminis, a small, thick-walled rounded pouch.

The female nymph-(Figs. 36-38). The only known specimen of the female nymph was recently described by the writer ('19) ${ }^{18}$ and is nearly full grown. The eighth sternum is similar to that of the adult, except that it is uniformly, though feebly, chitinized. The ventral valvulæ arise just behind the sternal margin and are straight, subcylindrical processes, bluntly pointed at the apices. The basivalvulæ are clearly defined by a transverse groove. The sternal region of segment nine still has its primitive horizontal position in line with that of segment

${ }^{18}$ Walker, E. M., Can. Ent., Vol. LI, 11, pp. 131-139. 1919. 
ten. Across its middle arise the dorsal and inner valves in the same transverse plane. They are likewise of subcylindrical form, the inner valvulæ pointed like the ventral pair, while the dorsal valvulæ have well-developed styli upon their apices, a primitive feature, unlike any of the Orthoptera at so late a stage. Judging by the comparative lengths of the valvulæ the styli evidently go to form the apices of the dorsal valvulæ. There is no trace of the intervalvular membrane, this structure being doubtless formed from the median part of the sternal area, both before and behind the bases of the inner valvulæ. The remaining parts of the sternum go to form the valvifers (antero-lateral region) and the broad bases of the dorsal valvulæ (postero-lateral region).

It will be seen that at this stage the ovipositor of Grylloblatta is distinctly more primitive in character than that of a Tettigoniid nymph of corresponding stage. This is seen in the form and position of the valvulæ and in the presence of styli. In these respects they approach the Blattidæ and Mantidæ, but the valvulæ of the ninth segment have not the terminal position, nor have the dorsal valvulæ the broad, flattened form found in these groups. In these respects the Blattids and Mantids are the more primitive and Grylloblatta occupies a position between them and the Tettigoniidæ.

\section{Phasmoidea.}

In this well circumscribed order the ovipositor is of a somewhat primitive type and is, at the same time, more or less degenerate and probably functionless in most cases. It is generally largely concealed by a hood-like subgenital plate, which as in the Orthoptera, is the eighth sternum. The end-segments (8 to 10 ) show no tendency to become abbreviated and the sternal surface of segment nine retains its primitive horizontal position in the same plane with that of segment ten. The abdominal spiracles are all situated in the pleural membrane. The cerci are always relatively short and unsegmented and the anal valves (supra-anal plate and paraprocts), though prominent, are not usually large nor densely chitinized.

In the remarkable little Phasmid, Timema californica Scudd. (Figs 39, 40), the genitaliz appear to be of very primitive form, but they may perhaps be more correctly described as of 
a "larval" type, i. e., they are probably to be looked upon as degenerate, functionless structures, whose development has been arrested at an early stage, as is not uncommonly the case in degenerate structures. The eighth sternum is but little produced over the bases of the ventral valvulæ, which are slender and flexible with broader basivalvulæ. The ninth segment is shorter than usual in this order, but the sternum is horizontal, its lateral parts, the valvifers, being larger and having a larval position in relation to the dorsal valves of the ninth tergite. They were erroneously regarded as basal segments of the dorsal valvulæ (basivalvulæ) by Crampton. The dorsal valvulæ are flexible, triangular flaps, whose bases meet the inner edges of the valvifers exactly. The term "dorsal" is here inappropriate, as they retain the larval position external to the inner valves, with which they are fused to within a short distance of the apices of the latter. Neither dorsal nor inner valvulæ are connected with the ventral pair. Having seen only one specimen of Timema, which was kindly lent by Prof. Crampton, I have not studied the internal relations of the valvulæ.

The tenth tergite is rather long dorsally, but narrowed ventro-laterally. Its apex is somewhat produced over the supraanal plate, which like the paraprocts, is rather long and pointed, though but thinly chitinized. The cerci are large and stout.

A less primitive ovipositor, but more typical of the order, is that of the common stick-insect, Diapheromera femorata Say. (Figs. 41-43). The valvulæ of this species are of considerable size, but quite soft and flexible. They are flattened dorsoventrally and arched towards the anus. The inner valvulæ lie as in Timema in the primitive position between the dorsal valvulæ (although in some genera they lie dorsal to the latter), with which they are united in a similar manner. This connection seems to be characteristic of the Phasmoids and it was for this reason that the inner valvulæ were mistaken by LacazeDuthiers (' 52 , loc. cit.) for a part of the dorsal valvulæ. There is little development of the intervalvular membrane and the rami are represented only by a short chitinous process on each side, at the angle of union with the dorsal valvulæ, these processes ending freely, there being no trace of either superior or inferior intervalvulæ. The underside of the inner valvulæ bears a very distinct though flexible ridge (Fig. 43), which fits 
in a corresponding groove in the ventral valvulæ (Fig. 41), but as the parts are soft no union is thus obtained. The dorsal valvulæ do not lie so flat as in Timema, but the primitive widely separated position is retained, their bases not becoming arched dorsad over the inner valvulæ. Their only strongly chitinized parts are the superior apophyses which are well developed and a small process just above the angle with the ventral valvulæ, and apparently representing the inferior apophyses. There is no trace whatever of the valvifer, but there is a small process. (pap) which seems to belong to the lower extremity of the ninth tergal apodeme. Both valvifer and apodeme, however, may be well developed in the Phasmoidea as shown by Lacaze-Duthiers in the genus Acrophylla. Their absence in Diapheromera is a degenerative feature. The basivalvulæ are also absent in this genus. The subgenital plate is of large size, but much smaller than in many other genera. The tenth segment is large, with an extensive sternal area, but the supra-anal plate and paraprocts, though prominent are much smaller than in Timema. The cerci are also relatively smaller.

There is considerable variation in the Phasmids in the size of the subgenital plate, the relative lengths, form and position of the valvulæ, but a firm, coherent structure, such as the ovipositor of the Orthoptera and Grylloblattoidea, does not, so far as we are aware, occur in this order. The apparently primitive form of the Phasmoid ovipositor may be largely due, as already suggested in the case of Timema, to imperfect or arrested development, but at the same time, it is probable that the Phasmoid ovipositor never reached a high degree of development.

\section{Mantoidea (Mantidæ).}

Of the single family comprising this order two species were studied, Stagmomantis carolina L. and Mantis religiosa L. They are so much alike in the parts with which we are concerned, that we may confine our attention in the main to the former, this having been the form which was most thoroughly studied.

In Stagmomantis (Figs. 44-49) there is a marked abbreviation of the eighth and ninth tergites, which also extend a shorter distance ventrad on the sides than the seventh and preceding 
segments, so that they are separated from their sterna by a wider extent of pleural membrane. The tenth tergite is also laterally reduced, but is prolonged backwards over the supraanal plate, taking the place of the latter, which is greatly reduced and feebly chitinized, as are also the larger paraprocts. The spiracles are all situated on the tergites, near their lateral margin. The cerci consist of about 15 short segments, which are but little flattened.

The ovipositor is of considerable size, but almost entirely concealed by a huge hood-like structure, which is the seventh sternum and is therefore not the homologue of the subgenital plate of the groups thus far discussed. Under cover of this hood and adherent to it is a bifid plate (Fig. 44), which overlaps the vulva. This is part of the eighth sternum and apparently the homologue of the subgenital plate of the Orthoptera and Phasmoidea. The vulva lies between a pair of median shelf-like valves. Extending forward from between the base of the valves is a thick fold with a chitinized edge (ar), upon which is a small opening of the spermatheca. In the natural position of the parts this orifice lies just above the vulva. The valvulæ are large, but of irregular shape and only partly chitinized. The dorsal pair overlaps the ventral and both are distally decurved and peculiarly lobed at their blunt apices. The ventral valvulæ are widely separated for some distance from their bases, this space apparently serving for the exit of the ova and secretions which form the ootheca. The basivalvulæ are usually distinct and heavily chitinized, being the firmest parts of the valvulæ. Just above the basivalvula is a small, but well-chitinized valvifer connecting the dorsal and ventral valvulæ in the usual way. In Crampton's figure of the ovipositor of Stagmomantis ${ }^{19}$ this plate is incorrectly labeled "basivalvula" (i. e., of the dorsal valvulæ). It bears only one apodeme, parallel to the antero-ventral margin and continued as a strong ridge across the pleural membrane to the tergites of segments eight and nine, opposite the intersegmental groove, where it is expanded into a short broad spur (pap), and is thence continuous with the short tergal apodemes of these two segments. (Fig. 48). The pleural apodeme is a thickening of the intersegmental furrow, and is marked externally by a distinct groove.

${ }^{19}$ Jour. N. Y. Ent. Soc., Vol. XXV, P1. XVI, Fig. 7, 1917. 
The dorsal valvulæ are close together and at their extreme bases they are joined by a fold of tough cuticle. Just behind this fold is the large superior intervalvula, which unites the two bases closely with one another and with the inner valvulæ. It consists of a stout, bilobed transverse bar connected below with a thin horizontal plate (hlm), which projects forward into the body and bears a median apodeme, which has the same muscular connections with the valvifers as that of the Gryllidæ and Tettigoniidæ.

The dorsal apophyses are short but stout, the ventral rather slender, but well chitinized and firmly united with the large, thin, ventral intervalvula. The inner valvulæ are of moderate length, but very close together, not enclosing a passage for the exit of the eggs. There is a considerable space between their lateral surfaces and the dorsal valvulæ. Like the other valvulæ, they are lobed and ridged, and they engage the ventral valvulæ ineffectively, by a slight tongue-and-groove joint. There is practically no intervalvular membrane and no pons, but the rami are strongly chitinized and fused with the transverse bar of the superior intervalvula. Their anterior extremities, however (Fig. 49), lie below the level of this sclerite on each side of the horizontal plate $(\mathrm{hlm})$ which seems to represent an invaginated intervalvular membrane. There is no connection between the ends of the rami and the inferior intervalvula, such as occurs in the Orthoptera.

A pair of small lobes project back from the inferior intervalvula between the inner valves. (cf. Blattoidea).

\section{Blattoidea (Blattidæ).}

In the cockroaches we find many of the peculiarities of the Mantidæ in a more pronounced form, as well as special characteristics of their own. The ovipositor is not only degenerate, but more or less greatly atrophied and completely concealed by the large "subgenital plate," which as in the Mantidæ is the seventh, not the eighth sternum. Crampton (loc. cit., p. 227), states that in the superorder Pandictyoptera, (later termed Panisoptera and including Blattidæ, Mantidæ and Isoptera), "the ventral portion of the terminal abdominal segments is typically overlapped by a backward prolongation of the eighth segment." He 'considers Holmgren (Termitenstudien. Anat- 
omische Untersuchungen, 1909) as being incorrect in designating this segment in the Isoptera as the seventh, believing that the first abdominal segment is not developed ventrally in this order. Allowance is made by Holmgren, however, for the missing segments for the subgenital plate is the sixth sternum by actual count except in some forms where a vestige of the first persists.

This enlarged seventh sternum is prolonged back to the end of the abdomen, thus enclosing a very large "genital cavity" (or "anal cavity," as it is sometimes called), in which the ovipositor is entirely hidden. In some genera such as Periplaneta and Blatta it bears a pair of apical moveable valve-like plates, which serve to close the opening of the genital cavity.

The eighth and ninth tergites are usually greatly abbreviated and the tenth tergite, though laterally narrowed and not continued inwards beneath the cerci to any extent, is often considerably produced backward between the cerci, overhanging the anus and substituting the supra-anal plate, which in adult cockroaches is wholly wanting. This tenth tergite is commonly termed the supra-anal plate by systematists, but it is better to restrict this term to the structure to which it has been generally applied, otherwise it loses its morphological significance.

The disappearance of the supra-anal plate in the Blattids and its substitution by the tenth tergite is the more complete expression of the same tendency indicated in the Mantids, where the true supra-anal plate, though present, is reduced and entirely covered by the tenth tergum. A similar condition is met with in the Isoptera (q. v.).

The Blattids also resemble the Mantids in having segmented cerci, though these are shorter and more flattened, and in many other respects, which will be noted in the following account.

As an example of a typical Blattid with a fairly well developed ovipositor we may take the common native cockroach, Parcoblatta pensylvanica De Geer, better known as Ischnoptera pensylvanica. Fig. 52, is an oblique or ventrolateral view of the terminal segments of this species, the seventh sternum ("subgenital plate") having been removed. Fig. 51 is a ventral view of the same parts, omitting those of the tenth anal segments. Fig. 51 is a similar view, but with the valves of the ovipositor forcibly bent forward and the right dorsal valvula cut away from the base. 
The ventral valvulæ, like those of the Mantids, are irregular, only partly chitinized and spread apart towards their bases. But here a strange modification is seen. The bases are suddenly enormously expanded and connected with one another by an arcuate, chitinous band, which narrows at the sides and, passing around behind the base, joins a broader plate in this situation. This arcuate band, or its equivalent, varies greatly in form in different Blattids and is clearly the homologue of the transverse sclerite (ar) or chitinous edge of the fold in the Mantids which bears the opening of the spermatheca. It appears to be a special characteristic of these two nearly allied orders. The posterior plates referred to are the basivalvulæ, which have reached this position by the spreading apart of the bases accompanied by an outward rotation. A similar shifting of the valve bases is noticeable in the Mantidæ, but is much less pronounced. In the immature Parcoblatta, up to the last instar, no such peculiarities are seen, the ventral valvulæ being close together with typical basivalvulæ, and this simple condition is retained in the adult of Cryptocercus punctulatus Scudd. (Fig. 59), the ovipositor in this form having been apparently arrested in development, in a manner closely comparable to that of the Phasmid Timema californica (see pp. 292-3).

Immediately behind each basivalvula is the large valvifer, which, as usual, connects the bases of the dorsal and ventral valvulæ and is continuous at its antero-lateral angle with a strong apodeme, which follows the constriction between segments eight and nine to the tergal margins of these segments and is in every way comparable to the similar apodeme in the Mantids. The valvifer is thus widely separated from the tergal margins by a membranous area, which is crossed by the intersegmental apodeme, their relations being essentially the same as in the Mantidæ, and but little different from those which are typical of the Orthoptera, in which the ninth tergal apodeme is really the homologue of the intersegmental apodeme. The longitudinal groove of the apodeme is plainly seen and marks the constriction between the two segments.

Between the valvifers are two large plates which are continuous with the shafts of the dorsal valvulæ, from which they are strongly bent outwards and downwards. These are simply the bases of the dorsal valvulæ, and are not unlike the expanded bases of these structures in Gryllus. The dorsal valvulæ are 
decidedly folded and irregular on the dorsal side and bilobed at the apices, though ventrally smooth. There is a prominent sub-basal process on the dorsal side (pvd) but it is unchitinized. It is perhaps represented in the Mantids by a minute lateral lobe, which is present in this situation. The expanded bases are united behind by a narrow strip of chitin, in front of which, closely connected with the bases, is the peculiarly shaped superior intervalvula. There is also a pair of short spurs (sap) which may represent the superior apophyses (not present in all Blattidæ) and a pair of slender rods with thin, anterior expansions, (iap), which surround the bases of the inner valves and meet in a somewhat heavier median portion (iv), just behind the ventral valve bases. These rods evidently represent the inferior apophyses, while the thicker median piece is the inferior intervalvula. The spermatheca opens a little behind this plate; in other forms, such as Blatta, directly upon it.

The inner valvulæ have much the same form as in Stagmomantis and as in this genus they are slender, close together, and lie in the hollow of the dorsal valvulæ, close to the latter and engage the ventral valvulæ very feebly. In their slightly expanded, flexible apices, the lack of a true intervalvular membrane, and the presence of a pair of ventral basal lobes, they also recall the Mantids. They are not fused with the superior intervalvula, however, but are connected with the latter by a peculiar ball and socket joint, the dorsal surface of the fused valve bases bearing a knob, which fits into a socket in the transverse part of the superior intervalvula. In front of the knob the fused valve-bases form a thin plate which is curved upwards $(\mathrm{hlm})$. This plate is similar in position to the plate (hlm) in Stagmomantis (Figs. 45, 49) and is doubtless its homologue, as in Stagmomantis this plate is likewise continuous with the bases of the inner valvulæ, as well as the superior intervalvula, of which it appears to form a part.

It will be seen from the foregoing description that, in spite of wide differences in the form and proportions of the various parts they are essentially similar in the Blattids and Mantids, the differences being of small weight, as compared with the many points of resemblance.

In addition to the structures described, there is a rather large, though ill-defined chitinized area behind the bases of the dorsal valves (ca), and serving for the attachment of muscles. 
This is a secondary deposit of chitin and does not represent a definite sclerite. It is not present in all Blattidæ.

A narrow chitinized strip possibly represents the tenth sternum in Parcoblatta. The supra-anal plate is wholly absent in the adult though its vestige is present in the young nymph. The paraprocts, on the other hand, are large, broad and rather flattened and the dorsal surfaces strongly chitinized. The cerci are of the usual Blattid type, the basipodite developed on the inner instead of the outer side.

The immature Blattid (e. g., Parcoblatta, Figs. 55-57) is remarkable for the very primitive condition of the ovipositor, which is indicated, (1) by the fact that the valvulæ all develop from the hind margins of their corresponding segments; (2) in the manner in which the dorsal valvulæ develop (vide infra); (3) in the broad flat form of their valves, as distinct from the slender inner and ventral valvulæ (cf. the Thysanura, Fig. 72), and (4) in the persistence of styli on the dorsal valvulæ until the last moult.

Development of the ovipositor (Parcoblatta). The stages here outlined were first described by Denny ('94) ${ }^{20}$ in the case of Blatta orientalis L. and are well known, but their significance has not been sufficiently emphasized. Figs 55, 56, 57 and 58 represent ventral views of segments eight and nine, a portion of seven (the seventh sternum being nearly all removed), of three immature stages and the adult Parcoblatta pensylvanica. The youngest nymph (Fig. 55) differs little from the male of the same stage except in the presence of a pair of small processes, on the hind margin of the eighth sternum and a small apical median fissure of the ninth sternum. Both sterna are well developed. In the next stage (Fig. 56) the eighth sternum is much narrower; the two little processes are greatly elongated and are marked off from the sternum by a slight constriction. They are now distinguishable as the ventral valvulæ, and the basivalvulæ are also indicated in the median sternal region. The two stylus-bearing lobes into which the sternum is divided have become relatively narrower, and the fissure between them has greatly deepened and widened at base, from which the rudiment of the inner valvulæ have arisen.

${ }^{20}$ Denny, A., Rept. 63, Meeting Brit. Assoc. Adv. Science, p. 818 (1894). 
In the third stage (Fig. 57) which represents the last nymphal instar, the eighth sternum is still narrower and has lost its distolateral angles. The ventral and inner valvulæ have changed but little, but the two lobes of the ninth sternum have greatly decreased in width, though the styli are practically unchanged. They are now clearly recognizable as the dorsal valvulæ.

The metamorphosis of this primitive condition into the complex structure of the adult is a transformation worthy of a higher order of insects, but the most significant feature in the entire process is the clear indication that the dorsal valvulæ are a part of the ninth sternum, and are homologous with the flat, stylus-bearing sternal lobes or "coxites" of the Thysanura. Their comparatively late development is no objection to their interpretation as such primitive structures, in view of the wellknown fact that organs, which are not functional until adult life is reached, are frequently retarded in development.

The ovipositor of Cryptocercus punctulatus (Fig. 59) presents an interesting structure intermediate between that of the adult and late nymphal stages of more typical roaches, such as Parcoblatta. The ventral and inner valves are quite like those of an immature roach, while the dorsal valves have something of the mature form, but are unusually simple. The valvifer is of remarkably generalised form and together with the wellmarked intersegmental apodeme bears a closer resemblance to these structures in the Mantids, than is found in any other Blattid I have examined.

The ovipositor of Cryptocercus is, however, very degenerate, the valvulæ and valvifers being very feebly chitinized and their inner connections greatly simplified. Thus, in view of the many details held in common by the more complex types of Blattid ovipositor and that of the Mantids, the simple structure found in Cryptocercus must be looked upon as at least partly due to arrested development, or the persistence of a larviform condition, rather than a truly primitive one. It is closely paralleled in the Phasmoidea by Timema californica.

It may be added that in certain respects Cryptocercus is highly specialized, namely in the enormous development of the seventh tergite, which is prolonged backwards over the remaining segments, so that the latter are completely concealed above and below. 


\section{Isoptera.}

Two species of this order were examined, Termopsis angusticollis Hagen and Leucotermes flavipes Kollar. The former is less degenerate in the structure of the genitalia and is therefore more favorable for comparison with other groups, besides being a much larger insect; so that the following remarks, unless otherwise stated, refer to this species.

The abdomen (Figs. 60,61), is tolerably broad and flattened, not unlike that of a cockroach in appearance, though the tergites are more uniform in size, the eighth, ninth and tenth being much abbreviated only towards the lateral margins. As in the Mantids and Blattids, the tenth tergite is prolonged over the supra-anal plate, which is obsolete in the adult; the paraprocts are broad, subtriangular and more distinctly, though not heavily, chitinized, and the short cylindrical cerci are composed of five segments, of which the apical one is much the longest and is probably compound. Termopsis also agrees with these two families in the concealment of the genitalia and sternal regions of segments eight and nine in a "genital cavity," under cover of the backward prolongation of the seventh sternum or "subgenital plate." As mentioned under the account of the Blattoidea, this plate is regarded by Crampton as the eighth sternum, but this is certainly erroneous. If the seventh sternum is cut away, a small chitinized flap is found, overlapping the genital orifice and also covering the bases of a pair of flattened lobes. This flap represents the free edge of the eighth sternum and the two lobes are the ventral valves. On each side of the lobes is a pair of plates, corresponding in position to the valvifers of the cockroach and, like the latter, thickened along the front margin. These plates are evidently the valvifers, the thickening representing the usual apodeme which occurs on the margin. It is not, however, continued laterad of the valvifer, there being nothing here to mark the line of junction of the eighth and ninth sterna.

Behind the overlapping by the ventral valves is a slender $\mathrm{V}$-shaped sclerite. This appears to represent the vestiges of the two slender bars which meet in a similar position in Parcoblatta and were interpreted as the inferior apophyses of the dorsal valvulæ, meeting in the inferior intervalvula. They at least represent some part of the bases of the dorsal valvulæ 
which have otherwise disappeared, together with the inner valvulæ. The remainder of the ventral surface of segments nine and ten is covered with a thinly chitinized cuticle.

In Fig. 63 the eighth abdominal spiracle may be seen in the conjunction immediately behind the eighth sternum, and close to the lateral margin, a position similar to that which it occupies in Parcoblatta.

It is sufficiently evident that the terminal abdominal structures of Termopsis are essentially like those of a Blattid in which the ovipositor has nearly disappeared. - In Leucotermes it has quite vanished and the cerci are reduced to two segments.

Judging by the more uniform length of the abdominal tergites, the cylindrical form of the cerci, and many other characters in other regions of the body it is probable that the ancestors of the Isoptera were more primitive than any Blattoidea of recent age, but the genitalia are distinctly more suggestive of the Blattids than the Mantids, and the wing venation of the primitive New Zealand termite Mastotermes, is decidedly more like that of the Blattoidea than the Mantoidea or Protoblattoidea, so that I am inclined to consider the order Isoptera as an offshoot from primitive Blattoid stock.

The results of these studies of the genitalia of the Mantoidea, Blattoidea and Isoptera strongly support Crampton's grouping of these orders in a superorder "Panisoptera."

\section{Dermaptera.}

In this order the genital segments are so highly modified that they give little information that is of value in determining the systematic position of the order. While in the majority of forms the ovipositor is entirely lacking, a small one is present in some genera of Protodermaptera, notably in the families Pygidicraniidæ and Echinosomidæ (Zacher, '11), ${ }^{21}$ so that we may conclude that the absence of this structure is a secondary condition. I have not seen any of these ovipositor-bearing forms, having, in fact, examined critically only two species of the order, viz., Forficula auricularia L. and Anisolabis maritima Bon. I have reproduced, however, figures of the ovipositor of Kalocrania and Echinosoma from Zacher (loc. cit.).

${ }^{21}$ Zacher, Friedrich, Zool. Jahrb., Bd. XXX, Syst., pp. 303-400, 80 Figs. (1911). 
In Forficula (Figs. 62-64) the eighth, ninth and tenth abdominal tergites are fused, but their boundaries are clearly defined. The eighth and ninth tergites are very short and concealed by the much, larger, overlapping seventh tergite; while the tenth is also very large, doubtless owing to the great development of the muscles concerned in the movement of the large forcipate cerci. The eighth and ninth sterna are concealed by the very large seventh sternum, and this feature, together with the reduction of segments eight and nine and the atrophy of the ovipositor is very suggestive of the "Panisoptera" (Blattoidea, Mantoidea and Isoptera); but unlike these groups, the tenth tergite does not replace the supra-anal plate, which is entirely free, and although small, is heavily chitinized and divided transversely into two separate sclerites, the distal of which is situated ventrally between the bases of the cerci, with which it is articulated. Possibly these two sclerites represent the eleventh tergite and the true supra-anal plate, as in the Acridoidea. Where three such sclerites are present (Pygidicraniidæ, Allosthetidæ, teste Zacher) they have been interpreted as representing the tergites of as many segments, viz., the eleventh, twelfth and thirteenth, or anal segment (pygidium, metapygidium and telson, or supra-anal plate), but the evidence for the existence of an additional segment between the eleventh and anal segments is quite insufficient. It is worthy of note, however, that these three sclerites are thus separately developed only in primitive genera.

Apart from the features mentioned above, there appears to be no evidence of close relationship between the Dermaptera and the Panisoptera.

The eighth and ninth sterna in Forficula are feebly chitinized and each is divided into two lateral plates, which were considered by Verhoeff ('03) ${ }^{22}$ to represent coxites. It is probable, however, that this division of the sterna is related to the former presence of an ovipositor, which occupied the median space, and this view is supported by the presence of an ovipositor in this situation in such genera as Kalocrania and Echinosoma, as judged by Zacher's figures. In these genera the ovipositor consists of but two pairs of valvulæ, belonging to the eighth and ninth segments. The former pair is long and slender $277-278$.

${ }^{22}$ Verhoeff, H. W. Nova Acta. Acad. Caes.-Leop., Vol. XXXI, 1903, pp. 
and obviously represents the ventral valvulæ. The other pair, from its lateral position and comparatively broad form is doubtless the dorsal valvulæ. Since the dorsal valvulæ represent the coxites of segment nine, the divided sternal plates, which are also present cannot be correctly termed coxites. They are more nearly comparable to the valvifers.

In some genera, such as Anisolabis (Fig. 65) there is also a small paired tenth sternum, but this is absent in Forficula. The two large sub-triangular plates (Figs. 66, 67), which are closely united with the margins of the tenth tergite and form part of the articulation with the cerci, were regarded by Verhoeff and Zacher as the coxites of segment ten, while Crampton identified them with the paraprocts. Crampton's view is the more probable in my opinion. Coxites are absent from segment ten in all other primitive insects, so that on a priori grounds we should not expect to find them in the Dermaptera. Paraprocts, on the other hand, are almost invariably present, and although these plates appear to belong to segment ten, there is no reason why, in such a highly modified group as the Dermaptera, they should not have been developed from the paraprocts, as these are usually closely connected with the margins of the tenth tergite, as, e. g., in the Blattoidea.

The spiracles all occupy the pleural membrane, the last pair, as in all the groups discussed, belonging to the eighth segment.

The unsegmented form of the cerci has probably been developed within the course of evolution of the order, as in immature stages of certain primitive forms (Diplatys, Karschiella and Bormansia) they are segmented.

\section{Embiidina (Embiidæ).}

This small group, which is undoubtedly of ordinal rank, has been considered by some writers (Enderlein and others) to be nearly allied to the Isoptera, while others (Crampton, Westwood, MacLachlan) find closer relations with the Plecoptera and Dermaptera. The latter view, is in the present writer's opinion, much nearer the truth. The resemblance to the Isoptera is largely due to the retention in both groups of many primitive characters and to parallel development along certain lines, such as the form and venation of the wings, the two- 
jointed cerci, the loss of the ovipositor, etc., but the special features of each group indicate a different line of descent.

As regards the female genitalia, but little evidence in support of either view is obtainable from this source alone. In Embia major, e. g., (Fig. 68) the general appearance of the terminal segments is much like that of a termite. The cerci are twojointed as in most termites, the tenth tergite is large and curves downward, covering the supra-anal plate, to which it is adherent. On the other hand, there is no extension of the seventh sternum to form a subgenital plate, in fact, no modification of either seventh or eighth sterna, and no lateral reduction of tergites eight, nine and ten as in the Isoptera. The paraprocts are large, but unchitinized and are distinct from the welldeveloped cercal basipodites.

Whereas in Termopsis there is evidence that the Isoptera are descended from ovipositor-bearing ancestors, there is no indication in Embia or any of the Embiidina that an ovipositor was ever present, the eighth and ninth sterna being quite simple. Since an ovipositor of primitive form is present in some Apterygota (Machilis, Lepisma, etc. of the Thysanura) and is undoubtedly homologous with that of Pterygote insects, it must have been present in the earliest representations of the latter, unless we are to regard the ovipositor-bearing Thysanura as descended from winged forbears, a view which I believe few will accept. This being the case, the Embiids, Plecoptera, etc., must likewise, (contrary to Crampton's opinion) be considered as secondarily without ovipositors. The fact that Campodea and other Thysanura have also no ovipositor does not affect the question. There is evidence that some of the Palaeodictyoptera had no ovipositor, while it is certain that some of them had one, and it was probably among the former that the ancestors of the Embiids and Plecoptera existed. The ovipositor, which was probably never highly differentiated, had already disappeared before these groups had acquired independent ordinal rank.

It is scarcely profitable to make a comparison between the Embiids and Grylloblatta until the structure of the male genitalia has been considered, but the following characters held in common between the females of the two orders may be mentioned: (1) There is no reduction in the length of the eighth and ninth tergites; (2) the spiracles are all situated in the 
pleural membrane; (3) neither the seventh nor the eighth sterna are prolonged into a sub-genital plate; (4) the cerci are segmented; (5) the paraprocts are feebly chitinized. The last feature has no special significance; the others indicate the primitive nature of both groups, but are otherwise negative in value, when taken alone.

No relationship to the Dermaptera or Orthoptera is even hinted at in the terminal abdominal segments of the females of Embiids.

\section{Plecoptera.}

As Crampton and others have pointed out, this order is in some respects the most primitive of existing Pterygote insects, particularly in the cervical and thoracic sclerites, wing venation and cerci. In the abdominal segments, of which ten are well developed, there is a tendency in many forms towards a considerable degree of chitinization of the pleural membrane. The ninth and tenth segments may be quite ring-like, even in the adult, while in the nymph all the segments may be annular. Crampton's suggestion that this annular form of segment may be a primitive one seems to me untenable. It is too exceptional among the Tracheata, and even within the Plecoptera there are all grades of chitinization of the pleural membrane. It is moreover, explained by the non-functional character of the abdominal spiracles in the nymph, in which respiration is performed by the tracheal gills, these structures sometimes (e. g., Pteronarcys) persisting in the adult in a reduced form.

The abdominal spiracles are all pleural in position, the eighth sternum is frequently more or less prolonged to form a subgenital plate, sometimes overlapping the ninth, or even the tenth, sternum. In some forms (e. g., Megarcys signata Hagen $)^{23}$ it is bilobed or bifid at apex, these lobes being slightly suggestive of vestigial ventral valvulæ. In most species of Pteronarcys there is no backward extension of the eighth sternum as a whole, but it bears a pair of slender processes, at or near the hind margin, which are probably true representatives of these valvulæ, being very similar to these structures as met

${ }^{23}$ Klapalek, Fr., Coll. Zool. Selys., Fasc. IV, p. 12, Fig. 6 (1912). Smith, Lucy Wright, Trans. Am. Ent. Soc., Vol. XLIII, pp. 433-489, Pls. XXIX-XXXIV (1917). 
with in certain Libellulid dragonflies. There is no other trace of the ovipositor in the Plecoptera, so far as I am aware, the ninth sternum being quite simple.

The tenth segment is well developed, often little smaller than the ninth. The tergite is often somewhat prolonged behind, concealing or partly covering the small supra-anal plate, with which it may be adherent. The paraprocts are large, generally well chitinized and usually intimately fused with the bases of the cerci so that the latter appear to arise from them. The cercal basipodites are thus not distinct from the paraprocts.

The cerci are typically multiarticulate, but are very variable in respect to both the number and the form of the segments.

These characters, taken by themselves, do not throw much light on the affinities of this group, but point to a very generalized structure, with secondary loss of the ovipositor. The primitive multiarticulate cerci are approached by those of the Grylloblattoidea, more closely than any other order, with the possible exception of some of the Ephemerida.

\section{Ephemerida.}

Although the Ephemerida and Odonata can hardly be called "Orthopteroid" insects, and their lines of descent from the Paleodictyoptera are undoubtedly quite distinct from any of the others considered, they deserve a few words, on account of their having retained certain very primitive characters.

The females of Ephemerida are chiefly remarkable from the fact that the oviducts open separately, and behind the seventh, instead of the eighth sternum. In some forms the seventh sternum is prolonged backwards into a spout-like structure, which apparently functions as an ovipositor (Morrison, '19) ${ }^{24}$ but this, of course, has no homology with any part of the Orthopterous ovipositor. The elongate, uniformly segmented abdomen, multiarticulate cerci and cerciform caudal filament, borne by the eleventh tergite are all marks of primitive structure. The anal valves are membranous and very slightly developed.

${ }^{24}$ Morrison, Emily Reed, Can. Ent., Vol. LI, No. 6, pp. 139-146 (1919). 


\section{Odonata.}

The form of the terminal segments of the dragonflies recalls the Phasmids, as suggested by Crampton, there being no abbreviation, but on the contrary, an elongation of all of them, as compared with the usual conditions. A fully developed ovipositor is present in all of the suborder Zygoptera and some of the Anisoptera (Aeshnidæ:-Aeshninæ and Petalurinæ), while a more or less reduced and simplified one occurs in the other groups. This ovipositor is remarkable in several ways. The dorsal valvulæ are broad, subtriangular, hood-like at the apices, and form a pair of flaps or covers for the ventral and inner valves, these structures serving as the actual instrument for making the punctures or incisions in which the eggs are placed. They thus resemble closely the broad sternal processes of segment nine in Lepisma, Machiiis and other Thysanura, which cover over the two pairs of valvulæ (representing the ventral and inner pairs) in quite a similar manner. They are still more interesting in the fact that they retain the styli in adult life as functional sense-organs, the Odonata being the only Pterygote order in which this is the case.

The ventral valvulæ also possess well developed basivalvulæ, the dorsal valvulæ superior and inferior apophyses. A superior intervalvula and intervalvular membrane are also present, but no inferior valvula, the strong rami of the inner valvułæ being articulated with the inferior apophysis.

There is also a valvifer, having typical connections with the valvulæ and ninth tergal apodeme.

The occurrence of these features in the Odonata is of interest in showing that they must be characters of very ancient origin and are in no way specially characteristic of Orthopteroid groups. 


\section{SUMMARY OF CHARACTERISTICS OF THE ORDERS.}

\section{Based. on the Terminal Abdominal Structures of the Females of Types Examined.}

Orthoptera-Eighth sternum more or less modified as a subgenital plate, but leaving ovipositor exposed; ninth sternum vertical or nearly so; valvifers (sometimes absent) in contact with ninth tergum and its marginal apodeme; ovipositor well developed (rarely vestigial or absent), with three pairs of valvulæ; basivalvulæ rarely well developed; a superior intervalvula connecting bases of dorsal valvulæ, which cover inner valvulæ and have two pairs of apophyses (superior sometimes indistinct or absent); inner valvulæ, when not vestigial, with rami, intervalvular membrane and pons, the rami with longitudinal ridge which fits into groove on ventral valvulæ; an inferior intervalvula connected separately with rami and inferior apophyses; tenth sternal region not defined, unchitinized; cerci unsegmented (two-segmented in Tridactylus); supraanal plate well developed, sometimes fused with but not concealed by tenth tergite; paraprocts usually well developed.

Nymph: Valvulæ all slender, dorsal and ventral pairs developing from ventral surface of ninth sternum; styli rarely distinct and usually disappearing at a very early stage.

Grylloblattoidea - Eighth sternum unmodified in form, ovipositor exposed; ninth sternum, valvifers and ninth tergal apodeme as in the Orthoptera; ovipositor well developed, with three pairs of valvulæ; basivalvulæ exposed, heavily chitinized, superior intervalvula absent; dorsal valvulæ covering inner pair; both pairs of apophyses present, inferior apophyses joining one another medially, there being no separate inferior intervalvula; inner valvulæ well developed, with rami, intervalvular membrane and pons; rami fused with inferior apophyses and connected with ventral valves as in Orthoptera; tenth segment annular; cerci, slender eight-segmented; supra-anal plate small, but not concealed by tenth tergite; paraprocts not large, unchitinized.

Phasmoidea-Eighth sternum modified, usually forming a very large flap-like subgenital plate, largely concealing the ovipositor; ninth sternal regional horizontal; valvifers and 
ninth tergal apodeme variable in development; ovipositor generally of considerable size, but the three pairs of valvulæ not firmly chitinized; dorsal valvulæ widely separated at base, not covering the inner pair and without a superior intervalvula; superior and inferior apophyses present, the latter widely separated; inner valvulæ united dorsal except distally and having sometimes an ineffective tongue-and-groove connection with ventral valvulæ; no intervalvular membrane or inferior intervalvula; tenth segment with distinct sternal region; cerci short, unsegmented; supra-anal plate usually small, paraprocts prominent.

Mantoidea-Tergites of segments eight and nine shortened; seventh sternum forming a very large subgenital plate concealing remaining sterna and ovipositor; eighth sternum greatly reduced; ninth, vertical or subvertical; valvifers separated from tergites, but connected across intervening membranous area by the intersegmented apodeme with eighth and ninth tergites; ovipositor of considerable size with three pairs of valvulæ, basivalvulæ heavily chitinized, widely separated, but connected by a chitinous arch or transverse bar; valvulæ of irregular form, and imperfectly chitinized; dorsal valvulæ covering inner pair, united at extreme base; superior intervalvula connecting both dorsal and inner valvulæ; dorsal valvulæ with two pairs of apophyses, the inferior apophyses joined by a large inferior intervalvula; inner valvulæ free from the latter without intervalvular membrane, but the internal (basal) prolongations of the rami connected by a thin plate which bears the median apodeme of the superior intervalvula; ventral valvulæ engaging inner by a feeble tongue-and-groove joint. Cerci subcylindrical, many-segmented; supra-anal plate vestigial, concealed by tenth tergite; paraprocts little chitinized.

Nymph (Mantis) similar to that of Blattoidea, but styli in last stage very minute.

Blattoidea-Abdominal segments flattened; tergites of eight and nine shortened; seventh sternum forming a very large subgenital plate, concealing remaining sterna and ovipositor; eighth sternum greatly reduced; ninth obliquely inclined; valvifers very large, separated from tergal margins, but connected across intervening membranous area with the eighth and ninth tergites by the intersegmented apodeme; ovipositor small, the three pairs of valvulæ of irregular form, more or less 
imperfectly chitinized and not coherent, though an ineffective engagement between the ventral and inner valves may occur; basivalvulæ very widely separated and rotated outwards, connected in front by a chitinous arch or bar; dorsal valvulæ covering inner pair, their bases greatly expanded, and medially united; superior intervalvula connected with dorsal valvulæ and with lamella formed by united bases of inner valvulæ, which are free from ventral valvulæ and lack an intervalvular membrane; inferior apophyses represented by slender bars connected with a vestigial inferior intervalvula; cerci of moderate length, flattened, segmented; supra-anal plate absent in adult, being substituted by tenth tergite; paraprocts flattened, generally well chitinized in part.

Nymph with valvulæ terminal, dorsal pair broad and flat, retaining styli until last stage; a vestigial supra-anal plate present.

Isoptera-Abdominal segments somewhat flattened; seventh sternum forming a large subgenital plate, covering the remaining sterna; eighth sternum ill-defined and greatly reduced; ninth, oblique or almost horizontal; valvifers, when present, widely separated from tergites, the intervening space not crossed by an apodeme; ovipositor absent or represented by a very reduced pair of ventral valvulæ and traces of the bases of the dorsal valvulæ; tergites eight, nine and ten laterally narrowed, the tenth replacing the supra-anal plate, which is absent in the adult; paraprocts broad, somewhat chitinized; cerci short, slender, with $2-5$ segments.

Dermaptera--Tergites of segments eight and nine greatly abbreviated and concealed by the seventh, tenth very large; seventh sternum forming a subgenital plate and concealing eighth and ninth sterna, which are medially divided; ovipositor usually absent, when present, reduced and lacking inner valvulæ; ventral valvulæ long and slender, dorsal valvulæ shorter and broader; tenth sternum sometimes represented by a pair of small sclerites; cerci very large and strong, forcipate, unsegmented (except in larvæ of some genera); supra-anal plate terminal, exposed, heavily chitinized, divided into pygidium and telson, sometimes with an intervening metapygidium; paraprocts ventral, consisting of flat, well-chitinized plates. 
Embiidina - Segments seven to nine unmodified, there being no specialized subgenital plate; ovipositor wholly absent; supra-anal plate practically absent, replaced by the large tenth tergite; paraprocts lobate, unchitinized; cerci two-jointed.

Plecoptera-Eighth sternum generally more or less modified to form a subgenital plate, sometimes with a pair of lobes or processes, possibly representing vestigial ventral valvulæ; ovipositor otherwise absent; ninth sternum horizontal, unmodified; ninth and tenth segments tending to be annular; supraanal plate variable, sometimes covered by a prolongation of the tenth tergite; cerci typically long and many-jointed, their basal segments fused with the large paraprocts.

\section{Comparison of Ovipositors of Pterygote AND APTERygote Insects.}

In the Apterygota the ovipositor is present only in the families Machilidæ and Lepismatidæ of the order Thysanura. It consists of two pairs of filiform gonapophyses, arising from the eighth and ninth sternum respectively. In Machilis sp., e. g., the separated eighth sternum has the appearance shown in Fig. 74. It is deeply bilobed, each lobe bearing a stylus while the gonapophyses occupy a median position between the lobes. They are very long and flexible and are divided by faint constrictions with numerous segments, with regularly arranged groups of setæ. The ninth sternum (Fig. 75) is similar to the eighth, except that the styli and sternal lobes are much longer, while the gonapophyses are shorter and more slender. In the natural position they reach about the same distance back. As compared with the eighth and ninth sterna, the preceding sterna (Fig. 73) differ not only in the absence of gonapophyses, but in the union of the stylus-bearing lobes and the presence of a triangular basal plate (ste), these parts being separated only by sutures. They also differ in the presence of eversible glands (cgl).

It is now generally recognized that the basal plate is the true sternite, while the lateral styli-bearing plates are coxites, these probably representing flattened coxæ of abdominal limbs which have otherwise disappeared (Haase, '89). ${ }^{25}$ The sterna of

${ }^{25}$ Haase, Erich, Morph. Jahrb., Vol. XV, pp. 331-435, Pls. XIV, XV (1889); Verhoeff. Zool. Anz., Vol. XXVI, pp. 60-77 (1903). 
segments eight and nine in Machilis are thus composed chiefly of the coxites, the sternite having practically disappeared. In some of the Lepismatidæ, however, (Nicoletia, Atelura) (Escherich, '05) ${ }^{26}$ the ninth segment has a distinct sternite overlapping the bases of the coxites just as in the thoracic segments. Comparing the eighth and ninth sterna of Machilis with those of the immature Blattid (Figs. 56-59) we have no difficulty in recognizing the coxites of segment nine in the flat stylus-bearing lobes, which become the dorsal valvulæ, and the gonapophyses of the same segment in the inner valvulæ of the Blattid, while the gonapophyses of segment eight in Machilis are the homologues of the ventral valvulæ of the Blattid. The styli of the latter segment have disappeared and the coxites are fused with the sternite, to form a "coxosternum" (Verhoeff, loc. cit.). It may be added that in Machilis, Lepisma, etc., the coxites of segment nine overlap the gonapophyses, forming a sort of sheath for them, just as they do in such Odonata as have retained a well-developed ovipositor. In Aeshna, e. g., (Fig. 71), the "genital valves" are the coxites of segment nine or dorsal valvulæ, and although more complex in form they have a very similar general position to those of Machilis, covering the other valvulæ in the same way, and bearing styli at their apices. There is no part of the anterior gonapophyses of Machilis that is distinctly recognizable as the basivalvulæ."

The homologies of the terminal abdominal structures of the female with those of the male, and other general questions will be discussed in Part II.

${ }^{26}$ Escherich, K. Das System der Lepismatiden, Zoologica, Bd. 18, Heft 43, pp. 1-164, 11 Pls. and 67 text figures (1905). 


\section{EXPLANATION OF PLATES.}

RefEREnce LetTering.

ap 8,9 -apodeme of segment 8 or 9 .

ar-basal arch.

bc-basipodite of cercus.

bs-basivalvula.

c-cercus.

cf-caudal filament.

clg-coxal gland

cx-coxite.

eg-egg guide.

ga-genital aperture or vulva.

hlm-internal lamella joining bases of inner valvulae.

iap-inferior apophysis.

int ap-intersegmental apodeme.

im-intervalvular membrane.

iv-inferior intervalvula.

lb-inferior lobes of inner valvulae.

$\mathrm{p}$-pons valvularum.

\section{pa-paraprocts.}

pap-process of intersegmental apodeme. pp-ventral prominence of pons.

pvd-sub-basal process of dorsal valvula,

rm-rami of inner valvulae.

sa-supra-anal plate.

sap-superior apophysis.

sp-spiracle.

spth-aperture of spermatheca.

st-sternum, sternal region.

ste-sternite.

st1-stylus.

$\mathrm{sv}$-superior intervalvula.

tg-tergite.

vd-dorsal valvula.

vf-valvifer.

vi-inner valvula.

vv-ventral valvula.

Plate XX.

1. Ceuthophilus lapidicola, adult; lateral view of end segments and ovipositor, ventral and inner valvulae bent downwards.

2. Same, not quite mature; dorsal view of ovipositor, left ventral valvula bent outwards, right not shown.

3. Same, adult; ventral view of ovipositor.

4. Same, inner view of structures at base of ovipositor.

5. Conocephalus fasciatus, adult; lateral view of end segments and basal part of ovipositor.

6. Same; ventro-lateral view.

7. Same; dorsal view of superior intervalvula and basal connections of inner valvulae.

8. Same; anterior view of base of ovipositor.

9. Same; ventral view of end segments of nymph four $\mathrm{mm}$. long.

10. Same; same view of nymph five $\mathrm{mm}$. long.

\section{Plate XXI.}

11. Gryllus assimilis, adult; lateral view of end segments and base of ovipositor.

12. Same; ventro-lateral view.

13. Same; dorsal view of ovipositor, left ventral valve bent outwards, right not shown.

1. Same; inner view of structures at base of ovipositor, left side.

15. Same; anterior view of base of ovipositor.

16. Oecanthus quadripunctatus, adult; lateral view of end segments and base of ovipositor.

17. Same; inner view of structures at base of ovipositor, left side.

18. Same, nymph; ventral view of end segments and ovipositor.

19. Ripipteryx forcipata Sauss., adult; lateral view of end segments and ovipositor.

20. Same; dorsal view.

21. Same; ventral view.

\section{Plate XXII.}

22. Melanoplus bivittatus, adult; postero-lateral view of end segments and ovipositor.

23. Same; postero-dorso-lateral view of cleared preparation.

24. Same; posterior view of ovipositor, with valvulae forced widely open.

25. Same; ventral view of ventral valvulae.

26. Acrydium ornatum, adult; lateral view of end segments and ovipositor.

27. Same; dorsal view.

28. Same, nymph; lateral view.

29. Same, nymph; dorsal view.

30. Same, adult; ventral view of ventral valvulae. 
Plate XXIII.

31. Grylloblatta campodeiformis, adult; lateral view of end segments and ovipositor.

32. Same; ventral view.

33. Same; dorsal view of ovipositor, left ventral valvula bent outwards, right not shown.

34. Same; inner view of structure at base of ovipositor, left side.

35. Same; anterior view of base of ovipositor.

36. Same, nymph; lateral view.

\section{Plate XXIV.}

37. Grylloblatta campodeiformis, nymph; ventral view of end-segments.

38. Same with ventral valvulae bent forward to expose inner valvulae.

39. Timema californica, adult; ventral view of end segments.

40. Same, lateral view.

41. Diapheromera femorata, adult; ventro-lateral view of end segments.

42. Same; lateral view of ovipositor; most of the 9 th tergite cut away to show the superior apophysis.

43. Same; dorsal view of ovipositor.

\section{Plate XXV.}

44. Stagmomantis carolina, adult; 8 th sternum and ventral.

45. Same; dorsal view of ovipositor, with dorsal valvulae spread apart.

46. Same; ventral view of ovipositor with ventral valvulae spread apart.

47. Same; lateral view of terminal segments and ovipositor with 7 th sternum bent downwards to expose the valvulae.

48. Same; inner view of structures at base of ovipositor.

49. Same; anterior view of base of ovipositor.

Plate XXVI.

50. Parcoblatta pensylvanica, adult; ventral view of ovipositor, the left ventrai valvula cut off at base.

51. Same; the valvulae bent forward to show their dorsal surfaces and the right dorsal valvula removed.

52. Same; ventro-lateral view of terminal segments, the 7 th sternum removed.

53. Same; ovipositor removed, cleared, and viewed from above. The ventral valvulae and the dorsal valvulae, except their bases, are omitted.

54. Same, last nymphal stage; ventral view of end segments with the 7 th sternum except a small part, removed.

55 to 58 . Same; successive stages in the development of the genitalia, ventral view, 7 th sternum removed, cerci 10 th and anal segments omitted. Fig. 58 is from the adult.

\section{Plate XXVII.}

59. Cryptocercus punctulatus, adult; ventral view of end segments, the 7 th sternum removed.

60. Termopsis angusticollis, adult; lateral view of end segments.

61. Same; ventral view of end segments, the 7 th sternum removed.

62. Forficula auricularia, adult; lateral view of end segments.

63. Same, dorsal view.

64. Same, ventral view, 7 th sternum removed.

65. Anisolabus maritima, adult; ventral view of end segments, the 7 th sternum removed.

66. Kalocrania marmoricrura, adult; ventral view of ovipositor and neighboring sclerites. (After Zacher.)

67. Echinosoma occidentale, adult; ventral view of ovipositor and part of segment 10. (After Zacher.)

\section{Plate XXVIII.}

68. Embia major, adult; lateral view of end segments.

69. Pteronarcys proteus, adult; ventral view of end segments. (After Smith.)

70. Perla lycorias, adult; ventral view of end segments.

71. Aeshna canadensis, adult; ventral view of end segments.

72. Machilis sp., adult; ventral view of end segments.

73. Same; 8th sternum and gonapophyses (ventral valvulae).

74. Same; 9th sternum and gonapophyses (dorsal and inner valvulae.) 


\section{$2 \mathrm{BHL}$ Biodiversity Heritage Library}

Walker, E. M. 1919. "The Terminal Abdominal Structures of Orthopteroid Insects: A Phylogenetic Study." Annals of the Entomological Society of America 12, 267-316. https://doi.org/10.1093/aesa/12.4.267.

View This Item Online: https://www.biodiversitylibrary.org/item/43720

DOI: https://doi.org/10.1093/aesa/12.4.267

Permalink: https://www.biodiversitylibrary.org/partpdf/193563

\section{Holding Institution}

Smithsonian Libraries

\section{Sponsored by}

Smithsonian

\section{Copyright \& Reuse}

Copyright Status: NOT_IN_COPYRIGHT

This document was created from content at the Biodiversity Heritage Library, the world's largest open access digital library for biodiversity literature and archives. Visit BHL at https://www.biodiversitylibrary.org. 